\title{
Inhibition of enzymatic browning in fruit and vegetable, review
}

\author{
Omar Y. AL-abbasy, Wathba I. Ali, Nashwan I. Al-lehebe* \\ Department of Chemisty, College of Education for Pure Science. University of Mosul, Iraq \\ * Corresponding author: nashwan78ibrahem@uomosul.edu.iq
}

\begin{tabular}{|c|c|}
\hline Article Information & Abstract \\
\hline $\begin{array}{l}\text { Received: } 11 / 01 / 2021 \\
\text { Accepted: } 25 / 02 / 2021\end{array}$ & $\begin{array}{l}\text { The second-largest cause of losing quality in vegetables and fruits (VFs) } \\
\text { is enzymatic browning (EB). As a result of polyphenol oxidases (PPOs), } \\
\text { EB leads to the color performance of vegetable and fruit yields. To }\end{array}$ \\
\hline Keywords: & $\begin{array}{l}\text { inhibit the activity of PPOs, chemical and physical methods have been } \\
\text { developed and several synthetic chemical compounds are widely used as }\end{array}$ \\
\hline $\begin{array}{l}\text { Enzymatic browning, } \\
\text { Polyphenol oxidase, Anti- } \\
\text { browning agents }\end{array}$ & $\begin{array}{l}\text { Anti-Browning Agents (ABA) in VFs products. In recent times, emphasis } \\
\text { was placed on customer-oriented food manufacturing innovations. } \\
\text { Customers have a tendency to encourage the usage of PPO inhibitors } \\
\text { that are natural and environmentally friendly. The aim of present review } \\
\text { is to illustrate the underlying mechanisms of PPO chemical inhibitor anti } \\
\text { browning action and current trends in some of these inhibitor studies. } \\
\text { Studies developed over the last decade have been reported and } \\
\text { discussed, such as Natural, chemical, physical, controlled atmosphere } \\
\text { and coating techniques to avoid EB. The purpose of this review article } \\
\text { will be to assemble and reveal an up-to-date demonstration of } \\
\text { browning inhibiting natural and synthetic compounds. The details } \\
\text { available in this review could also take to facilitate the ultimate objective } \\
\text { of developing new inhibitors of enzymatic browning (plant extracts, } \\
\text { natural and synthetic compounds) that are acceptable, healthy and } \\
\text { beneficial for the food industry. }\end{array}$ \\
\hline
\end{tabular}

\section{Introduction}

Browning has been the mechanism through which food converts brown owing to chemical reactions inside it. The browning process is among the oxidation processes in food science that occurs and is a remarkable subject for research in health, food, and nutrition technology research [1]. In most vegetables and fruits VFs products and seafood like shrimp, this reaction is considered undesirable; However, in certain foods like black tea, sauce, bread, cocoa, coffee, and raisins, it is essential to produce a distinctive hue and taste [2]. Depending on the mechanism, the browning reactions in foodstuff products are commonly allocated into enzymatic and non-enzymatic browning (NEB). The NEB process causes a browncolored substance without needing any enzyme participating via a chemical process containing a lone compound or numerous ingredients in food. Maillard reactions, oxidation of ascorbic acid (AA), and caramelization are included in NEB reactions in foods, these reactions happen typically in grouping instead of as insulated reactions since foods are composed of complicated components [3]. 
The EB reaction comprises the accomplishment of Polyphenol oxidase (PPO) present in food. Unlike NEB, it affects the dietary values of foodstuffs. Mechanical and physical stimulation during food peeling, wounding, and grinding transport, storage, and processing, EB occurs and tissue will be damaged. The phenolics and PPOs present in foods are exposed to air due to tissue deterioration, contributing to phenols being oxidized to quinones. Consequently, these compounds and their derivative products are polymerized via many reactants, creating an insoluble organic brown pigment called melanin [4]. Browning has many important nutrition, technology, and economic cost implications for the food industry. Scientists are especially interested in investigating browning control and the different ways that can be used to enhance this inhibition and eventually increase the stability of food [5].

\section{PPO Activity and its Prevention:}

PPO (EC: 1.10.3.1) is an enzyme-containing copper that belongs to the oxidoreductases family [6]. It is found and purified from VFs in particular quince [7], banana [8,9], pear [10] potatoes [11], avocados [12], eggplant [13], Chinese parsley [14], water yam [15], maize [16] and Sicilian tomatoes [17]. Since the activity of PPO is important for the control of EB, the factors influencing the activity of PPO, comprising the sort and quantity of intracellular phenol metabolites, $\mathrm{pH}$ and oxygen existence, which are aimed to reduce EB.

EB control classifies into two groups, physical and chemical. Many physical techniques are typically used such as coating, blanching, freezing, thermal dealing, and obstruction of oxidation. Enzymatic activity is inhibited by the denaturation of enzymes composed of proteins [18]. Chemical Anti-browning agents (ABA) (synthetic and natural) have been inhibited PPO activity which is commonly used in VFs products (Figure 1).

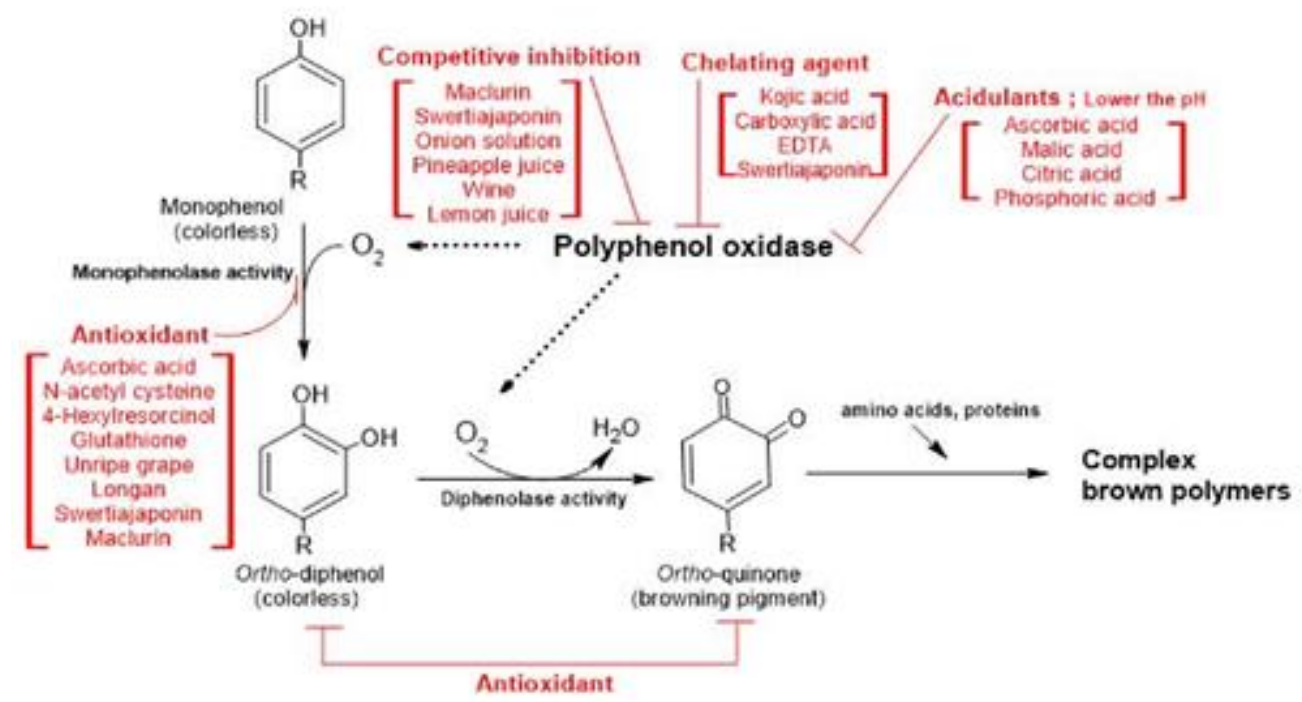

Fig. 1: Simplified EB processes and the mechanisms for inhibition of antibrowning agents [19].

\section{Physical techniques \\ Coatings:}

In general, coating substances have been used to prolong the life of VFs thru their warehousing. It involves applying a layer of a certain edible substance to the surface of the fruit. These agents' actions handel with the actions of reducing the lack of moisture and scent, delaying improvements in color and transmission of gas, and enhancement of the 
common form of the commodity storing [20]. Agents for the coating EB may be delayed and produce an improved browning. The general result of the application of a gel works more effectively against EB than immersion in a bath due to the choosy permeability to gel coatings gases [21]. To protect and preserve minimally processed fruits, edible coatings which can be used as the coatings have to afford a full or limited barrier to moistness, 02 , and $\mathrm{CO} 2$, enhance mechanical handling possessions, convey additives and elude volatile losses [22, 23].

\section{Blanching:}

The blanching of food is presented including the heat medium used: bleaching in boiling water and/or steam; bleaching by microwave has also been carried out in recent years. The blanching period varies based on the product, methods used, size, and state of maturity. The enzymatic systems responsible for sensory and vitamin modifications are inactivated by this procedure and oxidation is therefore limited. PPO's oxidative activity varies by temperature; to reach a plateau, it depends on temperature [24]. Blanching has certain drawbacks as well. It changes the reliability of the handled product in portion and provides a cooked flavor sometimes. This also develops damage to nutrients and leads to the declined weight of the product. For this last reason, by lowering nutritional and textural losses, the choice of the optimal combination time - heat treatment temperature must be made [25].

\section{Preservation in modified atmosphere}

For the oxidation process and PPO activities, oxygen is vitally important; changing the oxygen levels of the packaging atmosphere would seem to be a solution for controlling EB reactions. Fresh-cut VFs are usually processed by cutting, flaking, and rinsing, physically altering their original state $[22,26]$. The physical damage and injury caused by processing promote the levels of ethylene resulting in changes in the softness, color, and flavoring for the duration of storage, so availability of the quality of the freshy-cut product is a significant challenge $[27,28]$. It is, possible to resist the browning reaction by eliminating oxygen. To avoid contact with oxygen, the replacement of air with inert gas (N2 and CO2) [29]. Use of 02 impervious packaging material or dipping of food products of some other dose in a salt or sugar solution could be used [30,31]. Table 1 provides a summarized of the various coating solutions, blanching, and atmospheric Conservation. 
Table 1: Physical treatment on enzymatic browning

\begin{tabular}{|c|c|c|c|}
\hline product & Blanching method & Effectiveness & References \\
\hline Mango & Steam & Inhibition of PPO activity & {$[25]$} \\
\hline Indian gooseberry & Hot water & $\begin{array}{l}\text { All chemical properties affect by } \\
\text { blanching except A.A. content and } \\
\text { Maintains color. }\end{array}$ & {$[32]$} \\
\hline Red beet & Microwave & Inactivation of PPO. & {$[33]$} \\
\hline Potato & Superheated steam & $\begin{array}{l}\text { The combination therapy minimized } \\
\text { variations in texture and color. }\end{array}$ & {$[34]$} \\
\hline Brussels sprouts & $\begin{array}{l}\text { Water } \\
\text { Microwave/water } \\
\text { Coating method }\end{array}$ & $\begin{array}{l}\text { A processing microwave is improved } \\
\text { to maintain the product possessions }\end{array}$ & {$[35]$} \\
\hline Pomegranate & Starch + glycerol & $\begin{array}{l}\text { Browning is delaying too much with a } \\
\text { starch coating with seed oil }\end{array}$ & {$[36]$} \\
\hline Melon & Pectin & $\begin{array}{l}\text { Mechanical risk prevention during } \\
\text { storage }\end{array}$ & {$[37]$} \\
\hline Apple & Alginate & Firmness loss and Prevention of EB & [38] \\
\hline Papaya & Chitosan & Stopping of browning & [39] \\
\hline Mushroom & Aloe vera gel & $\begin{array}{l}\text { Both of them are more efficient for } \\
\text { browning delay. }\end{array}$ & {$[40]$} \\
\hline Apple & Atmosphere method & EB is postponed. & {$[41]$} \\
\hline Mushroom & $\begin{array}{l}\text { are balanced both thru } \\
\text { Argon or } \mathrm{N}_{2}\end{array}$ & $\begin{array}{l}\text { After storage, the foods are of } \\
\text { maximum physical quality. }\end{array}$ & {$[42]$} \\
\hline Carambole & Controlled atmospheres & $\begin{array}{l}\text { Usage of low } 02 \text { is not enough to } \\
\text { obstructive browning }\end{array}$ & {$[43]$} \\
\hline Mango & oxygen combinations & $\begin{array}{l}\text { The most Remarkable result is owing } \\
\text { to a decrease in } 02\end{array}$ & {$[44]$} \\
\hline
\end{tabular}

\section{Freezing:}

Freezing is a procedure that is sometimes used in VFs to avoid browning reactions. Indeed, for enzymatic reactions, freezing triggers a drop in available water. Lavelli and Caronni (2010) [45] discovered that a water operation in the apple, the PPO activity is no longer involved. Few studies are concerned with the enhancement of freezing as a form of preservation, as freezing results in permanent modifications of foodstuff freezing, like loss of firmness throughout cooling down [46]. Freezing may be a helpful process when it is not appropriate to thaw the product. Indeed, food quality after thawing sometimes, enzymatic reactions are altered and occur very quickly in the product. Therefore, to improve product shelf-life, freezing may be used, but in combination with some other techniques of preservation, such as soaking or blanching [47].

\section{Thermal treatment:}

To avoid EB, thermal methods are very effective, but this leads to a change in certain product parameters such as flavor and texture. A major challenge in this field is finding some non-thermal methodology. Irradiation, High hydrostatic pressure, ultrasonics, and pulsed electric fields are the procedures studied. The prime purpose of these various ways is to inhibit browning enzymes employing various techniques: pressure, electricity, or light. Queiroz et al. (2008) [48] reviewed studies on these better approaches up until 2007. The 
effectiveness of thermal treatments on the browning was evaluated by measuring the color parameters of purees from senescent plantain. The pulps were heated at $60^{\circ} \mathrm{C}$ for $35 \mathrm{~min}$ and the reduced browning was observed [49].

\section{Chemical Anti-Browning Agents}

\section{The Antioxidants /Agent Reducers.}

To suppress the initiation of browning, antioxidants can react with oxygen. They are also capable of reacting with intermediates, thus stopping the chain reaction and inhibiting the realization of melanin. The antioxidant $\mathrm{ABA}$ influences are based on environmental variables such as the composition of the atmosphere, $\mathrm{pH}$, temperature, and light [50, 51]. Antioxidants have been widely studied to avoid VFs browning [52, 53]. The single and mutual ABA properties of AA, N-acetyl cysteine, hexylresorcinol, reduced glutathione, and L- cysteine hydrochloride, on many fruits were investigated [54]. Better ABA activity was achieved when both $\mathrm{N}$-acetyl cysteine and reduced glutathione were combined [38]. The use of AA as an ABA is widespread. It appears that the mechanism underlying AA relies on its decreasing activity. While AA does not cooperate mostly with an enzyme, EB is inhibited by decreased oxidized substrates [53]. Some studies also indicate that a decrease in the precursor diphenols of enzymatically formed o-quinones can be attributed to the ABA function of AA [55]. Nevertheless, the ABA property of AA may not even be powerful after applied to freshly-cut pears. So if AA is entirely oxidized to the reduced form. Ortho-quinones can no longer be reduced to diphenols and browning is likely to continue due to the generation of melanin [56]. Other antioxidants such as vanillin and melatonin were reported as ABA [57].

New research has shown that swertiajaponin and maclurin in herbs are also powerful ABA action on sliced potato [58, 59], via suppressing the generation of reactive oxygen species (ROS) in vitro [60]. In vitro study, Maclurin limited the generation of ROS by about $80 \%$ and repressed the EB of the potato for a prolonged period of about five weeks, whereas AA decreased it by approximately 43\%. Past studies have confirmed the positive inhibitory effect of PPO by Moraceae family extract, particularly Ficus auriculata and Morus alba. The potent compounds consist of flavanones, flavones, and 2-arylbenzofurans [61, 62].

Table 2: Antioxidants compounds to prevent enzymatic browning

\begin{tabular}{lllc}
\hline Product & Compound & Effectiveness & References \\
\hline Bean & AA & Reducing the browning. & {$[63]$} \\
Pear & AA+ 4-hexylresorcinol & Synergistic effect to inhibition of PPO & {$[53]$} \\
Artichoke & cysteine & Efficient treatment to prevent browning & {$[64]$} \\
Pear apple & Glutathione & Inhibition of PPO & {$[58]$} \\
juice & Erythorbic acid & Oxygen scavenger & {$[65]$} \\
Fruit salad & N-acetylcysteine or & preventing of browning reaction & {$[54]$} \\
Pear & glutathione & Antioxidant & {$[57]$} \\
Quince & Melatonin & PPO Inhibition about & {$[66]$} \\
Apple & Phytic acid & & \\
\hline
\end{tabular}

\section{Chelating Agents}

Because they can produce or react with their substrates with $\mathrm{Cu}^{+2}$ complexes present in PPO, chelating compounds are indeed broadly then used to inhibit PPO activity, thereby suppressing EB [50]. Kojic acid is a metabolite that several species of penicillium and 
Aspergillus produce. It is a powerful copper ions chelator that includes $\mathrm{Fe}^{+3}$ and $\mathrm{Cu}^{+2}$ [67]. Therefore, binding to $\mathrm{Cu}^{+2}$ of kojic acid inactivates PPO. Nevertheless, Kojic acid is not normally used in food production, presumably since of the challenging process associated with its high cost and high price [50]. Most carboxylic acids are demonstrated to display anti-browning activity owed to their chelating or pH-lowering influences [52, 68]. The browning of apple slices treated with different carboxylic acids for three minutes was controlled for three hours. Malonic, tartaric, oxalacetic and oxalic acids demonstrated heavy inhibition of apple slice browning; moderate inhibition was observed for malic, lactic, pyruvic, and citric acids, while the poor inhibitory effect was detected for fumaric, formic, succinic, and acetic acid [69].

Although citric acid is not as powerful as other carboxylic acids, it has also been extensively used in the food industry as an ABA compound [70]. General identification of the protection, pleasurable acid taste, excessive water solubility, chelating and buffering characteristics of citric acid is attributable to its widespread application. Citric acid is thus applied to a variety of beverages, comprising ciders, wines, soft drinks, syrups, milk products, jellies, and candies, to increase sourness, natural flavor, the efficacy of antimicrobial additives, antioxidant ability and to minimize sucrose crystallization and EB [71]. Taking into account its widespread occurrence in nature, oxalic acid and its byproducts were being used as ABA for freshly- cut sliced apples [69], with strong ABA activity. SodiumEDTA is also commonly referred to as sodium salts supplied in the foodstuff manufacturing as metal chelating substances [55]. Some chelating agents are listed in table 3.

Table 3: Chelating agents of chemical compounds to prevent enzymatic browning

\begin{tabular}{lllc}
\hline Product & Compound & Effectiveness & References \\
\hline Lettuce & Citric acid & $\begin{array}{l}\text { Noncompetitive inhibitor of PPO } \\
\text { inhibition of PPO enzyme as } \\
\text { chelating agents }\end{array}$ & {$[72]$} \\
$\begin{array}{l}\text { Apple juice, Unripe } \\
\text { grapes juice }\end{array}$ & Kojic acid & $\begin{array}{l}\text { Inhibitory effect of browning } \\
\text { enzymatic activity }\end{array}$ & {$[73]$} \\
Loquat juice & Chlorogenic acid & Inactivating PPO & {$[74]$} \\
Unripe grape juices & Gallic acid & Low inhibitory effect on EB & {$[74]$} \\
Potato puree, Apple & Coumaric acid & Inhibitory effect of PPO activity & {$[76]$} \\
Lentil & EDTA & Inhibition of PPO activity & {$[77]$} \\
\hline
\end{tabular}

\section{Acidulants}

Acidulants are also widely used as ABA, particularly those that occur naturally in the tissues, and ascorbic, malic, citric, and phosphoric acids are composed. At pH 6-7, PPO is generally active, inactive, though below pH3. Decreasing the $\mathrm{pH}$ by acidulants and thus decrease PPO's activity of an enzyme. $[78,79]$. The EB of sugar cane juice, when treated with ascorbate or citrate, was efficiently inhibited below $\mathrm{pH} 4$. Citric acid and malic acids have been identified as the main chemicals that can inhibit banana PPO activity through further analysis of the fraction immediately eluted, [80]. Although tartaric acidifying agents contain acetic and malonic acids., they are seldom used alone to prevent EB. Other 
ABA, inhibitors of metabolites, such as vitamins, chelating agents and are often used to treat the acidifying agents $[78,52]$. Some acidulants are recorded in table 4

Table 4: Acidulants of chemical compounds effect on enzymatic browning

\begin{tabular}{cccc}
\hline Product & Compound & Effectiveness & References \\
\hline Apple & Oxaloacetic acid & & \\
Apple & Lactic acid & Inhibitory effects on EB because & [69] \\
Apple & Pyruvic acid & of lowering pH & \\
Apple & Formic acid & & \\
Unripe grapes juice & Malic acid & & \\
\hline
\end{tabular}

\section{Cyclodextrins (CD):}

Naturally, cyclodextrins are cyclic oligosaccharides creating from six, seven, or 8 connected monosaccharide glucose by (1-4) glycosidic bonds [81]. The use of CDs was suggested for the EB control in apple products [82]. In comparison to banana, sugarcane, and guava fruit juices, the pineapple, apple, and pear showed a better effect [83]. In the presence of maltosyl-b-CD, the color of fresh apple juice was evaluated. The effectiveness of $\mathrm{CD}$ as a browning inhibitor was determined by the difference between the colors observed in the CD-treated sample and the controls. The addition of the CD decelerated the EB of apple juice [84]. For their ability to bind non-covalently with PPO and their effect on enzyme activity, polysaccharides differing in structure and chemical nature were tested. PPO was inhibited by all selected polysaccharides, but CD showed maximum inhibition under optimum conditions. Other applications of $\mathrm{CD}$ as $\mathrm{ABA}$ consideration has been paid to compounds in fruit juices [85]. Various The evolution of color parameters of various fruit juices, such as peach juices, has been examined on CD [86], and grape [87]. The data shows that with PPO substrates, CD can form complexes, eliminating their oxidation to quinones and eventual polymerization to brown pigments. [85].

\section{Natural Anti-Browning Agents Honey:}

Honey is an excellent eatable coating agent because it is delicious and has antioxidant qualities that may well resist EB in freshly-cut fruit [20]. Ates et al., (2001) [88] indicated that PPO extracted from a fungus can inhibit by a peptide in honey. Honey has been shown to inhibit browning activity in raisins as an effective ABA [89], for freshly cutting mango [22], persimmon [26, 69], and apple [90]. The effects of honey dips with $\mathrm{CaCl} 2$ on the quality of nectarines have been investigated. Freshly-cut nectarine PPO activity starts to change on the day. Because the fresh-cut, browning, and darkening were not evident Day1, reduced the activity by dipping in honey solution $50 \%$ compared to a control sample, of PPO [91]. Inhibition parameters were reported for honey on ginger PPO. A 5\% (w/v) of honey exhibited (42.57\%) inhibition. With the rise in honey concentrations with all substrates used, there was an increase in the inhibition ratio [92].

Honey was considered by Gacche et al. (2009) [93] to be PPO activity inhibitor. Besides, Jeon and Zhao (2005) [90] study, honey was found to have an inhibitory effect against superoxide radicals, contributing to the EB reaction. being inhibited. The investigation of browning inhibition in apple slices, grape juice was observed [94, 95]. The mechanism varies depending on the diversity using of honey, PPO origin and the substrates used to inhibit PPO [96]. Haard and Simpson (2000) [97] showed that honey behaves as a chelating agent to inhibiting PPO. A short peptide has a molecular mass of 600 found in honey may therefore inactivate the enzyme from the active site of PPO by chelating copper. Also, its antioxidant properties have been shown by a high number of a compound such as flavonoids, phenolic acids and vitamins found in honey [98]. 


\section{Rice bran:}

Rice bran is a by-product of the rice milling process [99]. Rice bran is a source of numerous nutrients such as proteins, peptides, and several amino acids that have antioxidant properties, especially glutamic, asparagine, taurine, and glutamine [100, 101]. Kahn (1985) [102] reported that protein at the active site of PPO could inhibit EB by reacting with quinone to form colorless complexes or by direct inhibition of the enzyme and forming stable complexes with $\mathrm{Cu}^{2+}$. The EB inhibition of potato puree may involve cysteine and histidine that have shown high chelating activity and have been found in rice bran protein [101, 103]. The effect of rice bran protein extract (RBPE) on EB inhibition in vegetable and fruit puree has been investigated. In potato puree, RBPE showed the highest browning inhibition percentage, followed by apple and banana puree, respectively. At $\mathrm{pH}$ 4.0 and 5.0, RBPE inhibited browning and PPO inhibition compared to those at 6.0 and 7.0. RBPE, therefore, has the potential to be used in the industry as a natural ABA [104].

For their ability to inhibit EB in potatoes and apples, full-fatted rice bran extracts were evaluated and showed a more efficient inhibition of PPO compared to defatted. HPLC has identified five phenolic compounds in both (protocatechuic acid, vanillic acid, p-coumaric acid, ferulic acid, and sinapic acid) [76]. Using alkali extraction, the protein was extracted from defatted rice bran (Oryza sativa L.) The effect of its protein fractions on inhibition of EB in potato puree was investigated. The albumin fraction inhibited browning to a level similar to the fraction of glutelin, but among all the fractions, the former had the highest inhibition of potato PPO [105].

\section{Onion:}

Onion has numerous advantages as a healthy food because containing anthocyanins, kaempferol, quercetin as different functional compounds, isorhamnetin, and sulphoxides of cysteine as alkyl cysteine [106]. Also, it has been reported that onion extracts suppress EB of potato by inhibiting PPO activity. The browning of potatoes can not only be prevented by heated one but the fresh extract of onions also. The heated extract of onions appears to be more potent than the fresh ones. Depending on the heating temperature, the ABA effect on potato PPO by the onion extract was significant. Together, heat treatment and onion adding appear to assist as a positive approach to enhancing the color of apple juice and its nutritious content. However, apple juice when heated with onion shows not enriched values for these parameters only, but also improved values for those parameters significantly increased flavonoid concentrations [107]. The EB of pears was also suppressed by onion extracts. Onion extract based on water inhibited significantly pear PPO activity and was advance suppressed by the heated one and the inhibition was noncompetitive [108].

The inhibitory effect of ginger PPO activity was studied by onion extracts. The for both 4methyl catechol and pyrocatechol, heated extracts displayed a greater percentage of inhibition than nonheated extracts. It can be inferred that the ability of enzyme binding to substrates greater than fresh extracts may have been decreased by heated extracts [92]. Both heated and unheated onion extracts were found to exhibit similar inhibition types, which were mixed-type inhibitions. However, yam PPO was competitively inhibited [109] and cassava leaves PPO was non-competitively inhibited were found to have onion [110]. Onions have a thiol or sulfhydryl group that can interfere with PPO catalytic activity by binding copper at the active site of PPO. The antioxidant capacity of the flavonoid compound and thiol groups found in onions has been recognized, which can help control browning reactions also [111]. Heating has been suggested to significantly increase the functionality of onions, including the concentration of polyphenols, the activity of antioxidants, and the 
capacity of metal-chelating $[108,112]$. Besides, the supplementation of D-glucose and Lglycine further enhanced the suppressive influence of onion extract against enzymes [113].

\section{Others natural ABA:}

Unripe grapes have been shown to they contain greater amounts of polyphenols than ripened grapes. It has been reported that after making wines, three to six million tons of grape pomace every year have been generated. In addition, unripe grapes have been found to produce higher amounts of polyphenols than those of the ripened ones [114]. The largest antioxidant, ferric reduction, and anti-browning capabilities were shown by Merlot grapes [74]. Unripe grapes are likely to derive beneficial effects from their content of flavanol (epicatechin, catechin, epigallocatechin, and gallate) as well as phenolic compounds (caffeic, gallic, and chlorogenic acids). Caftaric acid competitively inhibited the activity of PPO among the main components and the inhibitory activity was greater than chlorogenic and caffeic acids [114].

Pineapple is a world-renowned fruit crop consumed fresh or in different refined ways. It is the type of the most widely used pineapple products due to its delicious flavor. Interestingly, the juice of pineapple is used to treatment browning as an agent. (Lozano et al. 1993) observed [115] that pineapple juice was relabeled to sulfite, a commonly used inhibitor for inhibiting fresh and dry apple rings from EB. Using various size pineapple juice prevented the EB of crude apple extracts by at least $26 \%$. The browning of banana slices was significantly suppressed by pineapple juice. The influence was an acceptable comparison to $8 \mathrm{mM}$ of AA. Malic and citric acids were confirmed by much more extensive analysis of the instantly eluted fraction as the main bioactive capable of $[80,115]$.

The effects of lemon juice on the browning sample of pastry dough were explored in a study. ABA a citric and AA effects of lemon juice were observed when added $5 \mathrm{~g}$ of lemon juice on the dough of pastry. The authors assumed that in lemon juice, citric and AA bind to the active center are associated with the greater ABA potential of lemon juice [116].

Fruits like rambutan and longan from Sapindaceae, which account for $24.9-40.7 \%$ and $52.9-74.7 \%$ of the entire fruit on a fresh weight basis, a significant amount of by-products are generated annually. While there are several functional components among these byproducts, which are discarded as waste compounds, excluding corilagin, ellagic acid, gallic acid, and geraniin [117]. Previous researchers have documented the inhibitory actions of Longan seed and peel extracts on PPO. The antioxidant function of the peel of longan occurs to be contributing to PPO inhibitory action [118]. Longan seed aqueous and ethanolic extract also inhibited the activity of PPO by more than $60 \%$ [119].

During fruit thinning, generated of by-products too, which are essential to increase the remaining fruit size, reduce the risk of limb breakage, and avoidance of an alternative bearing cycle. There has been a considerable amount of time and expense has been invested in this process [120]. Thinned fruits are typically abandoned, though. Therefore, these byproducts were used to gives the agricultural and food industries extra profit. Efforts have been underway to clarify new ways of using thinned fruits as ABA. A study illustrated the probable suppression of the EB catalyzed by PPO reaction through exposure to wreaked nectarine. The study indicated nectarine thinning extracts inhibited PPO derived from 
mushrooms. Thinned nectarine extract effectively suppresses EB during 8 days of storage, minimally treated peaches [121].

In addition, a low-cost by-product of tomato skin with a large content of lycopene and maybe contain a lycopene content about 14times greater than that of internal tissues [122]. Moreover, it has a high ability to be integrated. in the ABA treatments as an antioxidant agent. The lycopene microspheres were successfully used in a study to prevent EB and increase the fresh-cut apples' dietary consistency. In combination with TiO2 nanoparticles, heat extraction of lycopene from the skin of tomatoes achieves an excellent yield of lycopene extraction, with cis-lycopene isomers prevalent. In contrast, the integration of lycopene microspheres improved the beneficial properties of apples, demonstrating an improvement in phenolic compounds of up to 56 percent [123].

Table 5. Study influence fruits and vegetables by natural anti-browning agents

\begin{tabular}{|c|c|c|c|}
\hline Product & Compound & Effectiveness & References \\
\hline Onion & Pear juice & $\begin{array}{l}\text { Reduced browning by inhibition of } \\
\text { PPO }\end{array}$ & {$[124]$} \\
\hline Pine-apple & Banana slice & Effective by PPO inhibition & {$[80]$} \\
\hline Lemon & Pastry dough & Prevention of EB & {$[116]$} \\
\hline Unripe grape & Caffeic acid & Inhibition of PPO competitively & {$[114]$} \\
\hline Tomato skin & Apple & $\begin{array}{l}\text { Browning is reduced and even raised } \\
\text { some bioactive compounds }\end{array}$ & [123] \\
\hline $\begin{array}{l}\text { Tartary } \\
\text { buckwheat }\end{array}$ & Potato & Antioxidant & [125] \\
\hline Honey & $\begin{array}{l}\text { Grape juice } \\
\text { Persimmon }\end{array}$ & PPO inhibition, and antioxidant & $\begin{array}{l}{[95]} \\
{[26]}\end{array}$ \\
\hline Rice brane & Potato puree & $\begin{array}{l}\text { Antioxidant proportion of some } \\
\text { amino acids }\end{array}$ & [105] \\
\hline
\end{tabular}

\section{Toxic anti-browning agent}

The most prevalent procedure used during browning control in the food and beverage industries is the addition of sulfating agents. Sulfites are generally used to prevent potatoes, apples, mushrooms, and other fruits and vegetables from browning. Reducing the oquinones produced by PPO catalysis is the major impact of sulfites on enzymatic browning. Even if sulfites are so very capable of inhibiting other enzymatic browning reactions, they are used for foods and drinks is correlated with several negative features. Sulfites, particularly in some sensitive people, such as steroid-dependent asthmatics, are known to cause adverse health effects. Among this highly sensitive group, several deaths have resulted from the consumption of sulfurized foods. Sulfites can also release sulfur dioxide gas, in certain foods that harm the flavor of the handled product $[126,127]$.

\section{Conclusion:}

To ensure the quality of VF products, the advancement of anti-browning agents in the nutrition sector is essential. Predominantly, in terms of developing anti-browning agents, efficiency and price are important considerations. Recent trends in anti-browning agents, that being said, need to serve the customers who request care to natural sources, healthiness effects, and sustainability. Food ingredients, such as onion, lemon and grape, and diverse other nutritional supplements, were already considered for anti-browning characteristics. 
Most of them inhibit PPOs greatly and show biological activity. In addition, efforts are ongoing to clarify the anti-browning activities of food by-products and residues.

\section{References:}

1. Martínez, C., M. Corzo, D. Mar and M. Castillo (2012). Food Biochemistry and Food Processing. Ph.D., Benjamin K. Simpson (ed.). Wiley-Blackwell. 56-83.

2. Nirmal, N., S. Benjakul, M. Ahmad, Y. Arfat and P. Panichayupakar (2015). Undesirable Enzymatic Browning in Crustaceans: Causative Effects and Its Inhibition by Phenolic Compounds. Cri. Rev. Food Sci. Nut., 55 (14),1992-2003.

3. Tamanna, N. and M. Nahid (2015). Food processing and Maillard reaction products: effect on human health and nutrition. Int. J. Food Sci., 3,1-6.

4. Holderbaum, D. (2010). Enzymatic Browning, Polyphenol Oxidase Activity, and Polyphenols in Four Apple Cultivars: Dynamics during Fruit Development. Hort. Science, 45(8),1150-1154.

5. Kaanane, A. and T. P. Labuza (1989). The Maillard reaction in foods. Progress in Clinical and Biological Research, 304, 301-327.

6. Pretzler, M., A. Bijelic, and A. Romple (2017). Heterologous expression and characterization of functional mushroom tyrosinase. Sci. Rep. 7, 1810.

7. Rashan, A. I. (2020). Inhibitory and Kinetic Study of Partially Purified Tyrosinase from Iraqi Quince (Cydonia oblonga Miller) Fruit, M. A. Thesis. College of Education for pure science, University of Mosul, Iraq, 2020.

8. Carvalho, S., C. Wisniewski, P. O. Luccas and M. C. Schmidt (2013). Enzyme from banana (Musa sp.) extraction procedures for sensitive adrenaline biosensor construction. American Journal of Analytical Chemistry, 4,293-300.

9. Aydin, T., I. Gulcin and S.H. Alwase (2015). Purification and Characterization of Polyphenol Oxidase from Hemşin Apple (Malus communis L.). International Journal of Food Properties, 18,2735-2745.

10. Zhou, X., Y. Xiao and B. Liu (2018). Full inhibition of Whangkeumbae pear polyphenol oxidase enzymatic browning reaction by L-cysteine. Food Chem., 266,1-8.

11. Yang, $\mathrm{Zh}$. and $\mathrm{F}$. Wu, (2006). Catalytic properties of tyrosinase from potato and edible fungi. Biotechnology, 5 (3), 344-348.

12. Vieira, N. C., R. A. Ferreira, R. Valquiria, F. E. Guimarães, A. A. Queiroz, (2013). Selfassembled films containing crude extract of avocado as a source of tyrosinase for monophenol detection. Mat. Sci. Eng., 33 (7), 3899-3902.

13. Todaro, A.; R. Cavallaro, S. Argento, F. Branca and G. Spagna (2011). Study and characterization of polyphenol oxidase from eggplant (Solanum melongena L.). J. Agric. Food Chem., 59 (20),11244-11248.

14. Lin, H., A.W. Ng and C.W. Wong (2016). Partial Purification and Characterization of Polyphenol Oxidase from Chinese Parsley (Coriandrum sativum). Food Sci. Biotechnol., 25, 91-96.

15. Peng, X., D. Chao, Y. Haiyang, Z. Xiaoyu, Z. Xiuyuan, and W. Xiaoyu (2019). Purification and characterization of polyphenol oxidase (PPO) from water yam (Dioscorea alata). CYTA - Journal of food, 17(1), 676-684.

16. GulGuven, R.; N. Aslan, K. Guven, F.M. Bekler and O. Acer (2016). Purification and characterization of polyphenol oxidase from corn tassel. Cell. Mol. Biol., 62(13),611.

17. Brisolari, A. and D. Gonçalves (2014). Immobilization of Tyrosinase from Avocado Crude Extract in Polypyrrole Films for Inhibitive Detection of Benzoic Acid. Chemosensors, 2,182-192.

18. Devece, C., J.N. Rodríguez-López, L.G. Fenoll, J. Tudela, J.M. Catalá and F. García (1999). Enzyme inactivation analysis for industrial blanching applications: Comparison of 
a microwave, conventional, and combination heat treatments on mushroom polyphenoloxidase activity. J. Agric. Food Chem., 47, 4506-4511.

19. Moon, K.M., E. Kwon and Y. Choon (2020). Recent Trends in Controlling the Enzymatic Browning of Fruit and Vegetable Products. Molecules. 25(12), 2754.

20. Olivas, G. I., and G. V. Barbosa (2005). Edible coatings for freshcut fruits. Critical Reviews in Food Science and Nutrition, 45(7-8), 657-670.

21. Oms-Oliu, G., M. Alejandra, L. Alandes, P. Varela, M. Hernando, I. Perez, S. Fiszman, and O. Martin (2010b). Recent approaches using chemical treatments to preserve the quality of fresh-cut fruit: A review. Post. Bio. Tech., 57(3), 139-148.

22. Supapvanich, S. and P. Boonyaritthongchai (2016). Visual appearance maintenance of fresh-cut mango fruit by honey dip. Int. Food Res. J. 23, 389e394.

23. Song, H.Y., W.S. Jo, N.B. Song and K.B. Song, (2013). Quality change of apple slices coated with Aloe vera gel during storage. J. Food Sci. 78, 817-822.

24. Özel, A., A. Colak, O. Arslan and M. Yildirim (2010). Purification and characterization of a polyphenol oxidase from Boletus erythropus and investigation of catalytic efficiency in selected organic solvents. Food Chem., 119(3),1044-1049.

25. Ndiaye, C., Xu, S.-Y., \& Wang, Z. (2009). Steam blanching effect on polyphenol oxidase, peroxidase, and color of mango (Mangifera indica L.) slices. Food Chemistry, 113(1), 92-95.

26. Ergun, M. and N. Ergun (2010). Extending the shelf life of fresh-cut persimmon by honey solution dips. J. Food Process. Preserv., 34, 2-14.

27. Supapvanich, S. and G.A. Tucker (2013). The effect of 1-methyl cyclopropane (1-MCP) on quality and cell wall hydrolases activities of fresh-cut muskmelon (Cucumis melo var reticulatus L.) during storage. Food Bio. Technol., 6, 2196-2201.

28. Lamikanra, O., J.C. Chen, D. Banks and P.A. Hunter (2000). Biochemical and microbial changes during the storage of minimally processed cantaloupe. J. Agric. Food Chem., $48,5955-5961$.

29. Yousuf, B., O.S. Qadri, and A.K. Srivastava (2018). Recent developments in the shelf-life extension of fresh-cut fruits and vegetables by application of different edible coatings: A review. LWT Food Sci. Technol. 2018, 89, 198-209.

30. Murr, D.P. and Morris, L.L. (1974) Influence of $\mathrm{O}_{2}$ and $\mathrm{CO}_{2}$ on o-diphenol oxidase activity in mushrooms. J. Am. Soc. Hortic. Sci., 99, 155-158.

31. Banerjee, A., P. Suprasanna, P.S. Variyar and A. Sharma (2015). Gamma irradiation inhibits wound-induced browning in shredded cabbage. Food Chem., 173, 38-44.

32. Prajapaty, V. K., Nema, P. K., \& Rathore, S. S. (2011). Effect of pretreatment and drying methods on quality of value-added dried aonla (Emblica Officinalis Gaertn) shreds. Journal of Food Science and Technology, 48(1), 45-52.

33. Latorre, M. E., Bonelli, P. R., Rojas, A. M., \& Gerschenson, L. N. (2012). Microwave inactivation of red beet (Beta vulgaris L. var. conditiva) peroxidase and polyphenoloxidase and the effect of radiation on vegetable tissue quality. Journal of Food Engineering, 109(4), 676-684.

34. Sotome, I., Takenaka, M., Koseki, S., Ogasawara, Y., Nadachi, Y., Okadome, H., \& Isobe, S. (2009). Blanching of potato with superheated steam and hot water spray. LwtFood Science and Technology, 42(6), 1035-1040.

35. Vina, S. Z., D. F. Olivera, C. M. Marani, A. Mugridge, and R. H. Mascheroni (2007). Quality of Brussels sprouts (Brassica oleracea L. gemmifera DC) as affected by blanching method. J. Food Eng., 80(1), 218-225.

36. Oz, A. T., \& Ulukanli, Z. (2012). Application of Edible Starch-Based Coating Including Glycerol Plus Oleum Nigella on Arils from Long-Stored Whole Pomegranate Fruits. Journal of Food Processing and Preservation, 36(1), 81-95. 
37. Ferrari, C. C., Sarantopoulos, C. I. G. L., Carmello-Guerreiro, S. M., \& Hubinger, M. D. (2011). Effect of Osmotic Dehydration and Pectin Edible Coatings on Quality and Shelf Life of Fresh-Cut Melon. Food and Bioprocess Technology, 1-12.

38. Rojas, M.A., L. Sobrino, T. Soledad, and B. Martín (2009). Browning inhibition in fresh-cut 'Fuji' apple slices by natural antibrowning agents. J. Food Sci., 71,59-65.

39. Gonzalez, G. A., Valenzuela-Soto, E., Lizardi-Mendoza, J., Goycoolea, F., Martinez-Tellez, M. A., Villegas-Ochoa, M. A., Monroy-Garcia, I. N., \& Ayala-Zavala, J. F. (2009). Effect of chitosan coating in preventing deterioration and preserving the quality of fresh-cut papaya 'Maradol'. Journal of the Science of Food and Agriculture, 89(1), 15-23.

40. Mohebbi, M., Ansarifar, E., Hasanpour, N., \& Amiryousefi, M. R. (2012). Suitability of Aloe Vera and Gum Tragacanth as Edible Coatings for Extending the Shelf Life of Button Mushroom. Food and Bioprocess Technology, 5(8), 3193-3202.

41. Wu, Z. S., Zhang, M., \& Wang, S. (2012). Effects of high-pressure argon treatments on the quality of fresh-cut apples at cold storage. Food Control, 23(1), 120-127.

42. O'Beirne, D., Murphy, E., \& Eidhin, D. N. (2011). Effects of Argon Enriched Low-Oxygen Atmospheres and High-Oxygen Atmospheres on the Kinetics of polyphenol oxidase (PPO). Journal of Food Science, 76(1), E73-E77.

43. Teixeira, G. H. A., Durigan, J. F., Alves, R. E., \& O'Hare, T. J. (2008). The response of minimally processed carambola to chemical treatments and low-oxygen atmospheres. Postharvest Biology and Technology, 48(3), 415-421.

44. De Souza, B. S., O'Hare, T. J., Durigan, J. F., \& de Souza, P. S. (2006). Impact of atmosphere, organic acids, and calcium on quality of fresh-cut 'Kensington' mango. Postharvest Biology and Technology, 42(2), 161-167.

45. Lavelli, V.and P. Caronni (2010). Polyphenol oxidase activity and implications on the quality of intermediate moisture and dried apples. European Food Research and Technology, 231(1), 93-100.

46. Shomer, I., H. Borochov, B. Luzki, and U. Merin (1998). Morphological, structural, and membrane changes in frozen tissues of Madjhoul date (Phoenix dactylifera L.) fruits. Postharvest Biology and Technology, 14(2), 207-215.

47. Gossinger, M., S. Moritz, M. Hermes, S. Wendelin, H. Scherbichler, H. Halbwirth, K. Stich, and E. Berghofer (2009). Effects of processing parameters on color stability of strawberry nectar from puree. J. Food Eng., 90(2), 171-178.

48. Queiroz, C., L. Mendes, E. Fialho, and V. Valente (2008). Polyphenol oxidase: Characteristics and mechanisms of browning control. Food Rev. Int., 24, 361-375.

49. Arlette, A., N. Guessan, K. Olivier, and J.T. Gonnety (2018). Effect of Chemical and Thermal Treatments on Browning Inhibition of Senescent Plantain (Musa paradisiaca) Puree for Semolinas Preparation. American Journal of Biochemistry, 2018, 8(4),7584

50. Lindley, M.G. (1998). The impact of food processing on antioxidants in vegetable oils, fruits, and vegetables. Trends Food Sci. Technol., 9, 336-340.

51. Ioannou, I. and M. Ghoul (2013). Prevention of enzymatic browning in fruit and vegetables. EJLST, 9, 310-341.

52. Singh, B., K.Suri, K. Shevkani, A. Kaur, A. Kaur, and N. Singh (2018). Enzymatic browning of fruit and vegetables: A review. In Enzymes in Food Technology; Springer: Gateway East, Singapore, pp. 63-78.

53. Arias, E., J. González-Buesa, R. Oria and P. López Buesa (2007). Ascorbic acid and 4hexylresorcinol effects on pear PPO and PPO catalyzed browning reaction. J. Food Sci., 2007, 72, 422-429.

54. Oms-Oliu, G., I. Aguiló and O. Martín (2006). Inhibition of browning on fresh-cut pear wedges by natural compounds. J. Food Sci., 71, 216-224.

55. McEvily, A.J., R.Iyengar and W.S. Otwell (1992). Inhibition of enzymatic browning in foods and beverages. Crit. Rev. Food Sci. Nutr., 32, 253-273. 
56. Nicolas, J., F. Richard, P. Goupy, and S. Aubert (1994). Enzymatic browning reactions in apple and apple products. Crit. Rev. Food Sci. Nutr., 34, 109-157.

57. Rashan, A.I. and O.Y. AL-abbasy (2020). The Effect of Some Antioxidants Compounds on Enzymatic and Nonenzymic Browning of Quince Juice During Thermal Treatment, Journal of Education and Science, 29 (4), 206 - 221.

58. Lee, B.; Moon, K.M.; Lee, B.S.; Yang, J.H.; Park, K.I.; Cho, W.K.; Ma, J.Y. (2017). Swertiajaponin inhibits skin pigmentation by dual mechanisms to suppress tyrosinase. Oncotarget, 8, 95530-95541.

59. Moon, K. M., K. C. Young, J. Yeul and B. Lee (2019). Xanthone-related compounds as an anti-browning and antioxidant food additive. Food Chem., 274, 345-350.

60. Moon, K.M., B. Lee, W.K. Cho, B.S. Lee, C.Y. Kim and J.Y. Ma (2018). Swertiajaponin as an anti-browning and antioxidant flavonoid. Food Chem., 252, 207-214.

61. Burlando, B., M. Clericuzio and L. Cornara (2017). Moraceae plants with tyrosinase inhibitory activity: A review. Med. Chem., 17, 108-121.

62. Paudel, P., Seong, S.H., Wagle, A., Min, B.S., Jung, H.A., and J.S. Choi, (2020) Antioxidant and anti-browning property of 2-arylbenzofuran derivatives from Morus alba Linn root bark. Food Chem., 309, 125739.

63. Sikora, M., M. Świeca Effect of ascorbic acid postharvest treatment on enzymatic browning, phenolics and antioxidant capacity of stored mung bean sprouts Food Chem 2018 Jan 15;239:1160-1166.

64. Amodio, M. L., A. B. Cabezas, G. Peri and G. Colelli, (2011). Post-cutting quality changes of fresh-cut artichokes treated with different anti-browning agents as evaluated by image analysis. Post. Bio. Tech., 62(2), 213-220.

65. Gautam, S.; Sharma, A. Purification and characterization of polyphenol oxidase (PPO) from eggplant (Solanum melongena). Food Chem. 2012, 134, 1855-1861.

66. Du, Y. J., Dou, S. Q., \& Wu, S. J. (2012). Efficacy of phytic acid as an inhibitor of enzymatic and non-enzymatic browning in apple juice. Food Chemistry, 135(2), 580-582.

67. Chen, Y.H., P.J. Lu, C. Hulme and A.Y. Shaw (2013). Synthesis of kojic acid-derived copperchelating apoptosis-inducing agents. Med. Chem. Res., 22, 995-1003.

68. Bala, T., V. Prasad, M. Sastry, M.U. Kahaly and U.V. Waghmare (2007). Interaction of different metal ions with carboxylic acid group: A quantitative study. J. Phys. Chem., 111, 6183-6190.

69. Son, S.M., K.D. Moon and C.Y. Lee (2001). Inhibitory effects of various antibrowning agents on apple slices. Food Chem. 73, 23-30.

70. Pizzocaro, F., D. Torreggiani and G. Gilardi (1993). Inhibition of apple PPO by ascorbic acid, citric acid, and sodium chloride. J. Food Process. Preserv., 17, 21-30.

71. Soccol, C., L. Vandenberghe, C. Rodrigues, and A. Pandey (2006). New perspectives for citric acid production and application. Food Technol. Biotechnol., 44, 141-149.

72. Altunkaya, A. and V. Gökmen, (2009). Effect of various anti-browning agents on phenolic compounds profile of fresh lettuce (L. Sativa). Food Chem., 117, 122-126.

73. Shahryar S. (2013). "Partial purification and characterization of polyphenol oxidase from tomatoes (solanum Lycopersicum)". International Journal of Advanced Biological and Biomedical Research,1(6): 637-648.

74. Tinello, F. and A. Lante (2017). Evaluation of antibrowning and antioxidant activities in unripe grapes recovered during bunch thinning. Aust. J. Res., 23, 33-41.

75. Ding, C.K.; Chachin, K.; Ueda, Y.; Wang, C.Y. (2002) Inhibition of loquat enzymatic browning by sulfhydryl compounds. Food Chem., 76, 213-218.

76. Sukhontha S., K. Kaewka and C. Theerakulkait (2016). Inhibitory effect of rice bran extracts and its phenolic compounds on polyphenol oxidase activity and browning in potato and apple puree. Food Chemistry,190, 922-927

77. Sikora M., Świeca M., Franczyk M., Jakubczyk A., Bochnak J., and Złotek, U. (2019). Biochemical properties of polyphenol oxidases from ready-to-eat lentil (Lens 
culinaris Medik.) sprouts and factors affecting their activities: A search for potent tools limiting enzymatic browning. Foods, 8(5), 154.

78. Hithamani, G., H. Medappa, C. Arugakeerthy, K. Ramalakshmi, and K. Raghavarao (2018). Effect of adsorbent and acidulants on enzymatic browning of sugarcane juice. $J$. Food Sci. Technol., 55, 4356-4362.

79. Calder, B. L., Skonberg, D. I., Davis-Dentici, K., Hughes, B. H. and Bolton, J. C. (2011). The Effectiveness of Ozone and Acidulant Treatments in Extending the Refrigerated Shelf Life of Fresh-Cut Potatoes. Journal of Food Science, 76(8), 492-498.

80. Chaisakdanugull, C., C. Theerakulkait and R.E. Wrolstad (2007). Pineapple juice and its fractions in enzymatic browning inhibition of banana [Musa (AAA Group) Gros Michel]. J. Agric. Food Chem., 55, 4252-4257.

81. Szente, L. and J. Szejtli (2004). Cyclodextrins as food ingredients. Trends Food Sci. Technol., 2004, 15, 137-142.

82. Ozoglu, H. and A. Bayindirli (2004). Inhibition of enzymatic browning in cloudy apple juice with selected antibrowning agents. Food Control 13, 213-221.

83. Virendra, S., B. Rekha and S. Singhal (2015). Interaction of polyphenol oxidase of Solanum tuberosum with $\beta$-cyclodextrin: Process details and applications, International Journal of Biological Macromolecules, 80, 469-474.

84. Jose, M. L., N.D. Estrella, J. P. Antonio, S. F. Alvaro and C. Garcia (2007). Reaction's mechanism of fresh apple juice enzymatic browning in the presence of maltosyl-bcyclodextrin. J. Inc. Phenom. Mac. Chem., 57(1), 219-222.

85. López, J.M., P. Rodríguez and C. F. García (2014). Cyclodextrins and antioxidants. Crit. Rev. Food Sci. Nutr., 54, 251-276.

86. López, J.M., A.J Pérez, Á. Carbonell and C. F. García (2020). Use of natural and modified cyclodextrins as inhibiting agents of peach juice enzymatic browning, Molecules, 25, 2754-2769.

87. Núñez, D. E., M. Serrano, A.J. Pérez and J.M. López (2005). Polyphenol oxidase from dominga table grape. J. Agric. Food Chem., 53, 6087-6093.

88. Ates, S., S. Pekyardimci and C. Cokmus (2001). Partial characterization of a peptide from honey that inhibits mushroom polyphenol oxidase. J. Food Biochem., 25, 127-137.

89. McLelan, M.R., R.W. Kime, C.Y. Lee and T.M. Long (1995). Effect of honey as an antibrowning agent in light raisin processing. J. Food Process. Preserv.,19, 1-8.

90. Jeon, M. and Y. Zhao(2005). Honey combination with vacuum impregnation to prevent enzymatic browning of fresh-cut apples. Int. J. Food Sci. Nutr., 56, 165-176.

91. Wen, B., X. Wu, Y. Boon, L. Xu, H. Pan, P. Xu, and Y. Wu (2018). Suriyan Supapvanichd. Agriculture and Natural Resources, 52,140-145.

92. Lim, W. Y., and W. W. Chen (2018). Inhibitory effect of chemical and natural antibrowning agents on polyphenol oxidase from ginger (Zingiber officinale Roscoe). J. Food Sci. Technol., 55(8), 3001-3007

93. Gacche, R.N., B.T. Shinde, N.A. Dhole, M.M. Pund and A.D Jadhav (2009). Evaluation of floral honey for inhibition of polyphenol oxidase-mediated browning, antioxidant and antimicrobial activities. J. Food Biochem.,33, 693-706.

94. Oszmianski, J. and C. Y. Lee, (1990). Inhibition of polyphenol oxidase activity and browning by honey. J. Agric. Food Chem., 38, 1892.

95. Lee, C. Y. and R. W. Kime (1990). Stabilization of Wine with Honey and $\mathrm{SO}_{2}$, U.S. Patent $4,900,564$.

96. Lozano, JE (2006). Fruit manufacturing: scientific basis, engineering properties, and deteriorative reactions of technological importance. Springer Science, New York

97. Haard NF. and BK. Simpson (2000). Seafood enzymes: utilization and influence on postharvest seafood quality. CRC Press, Boca Raton 
98. Lee, MC (2013). United States Patent Application No. 13/336,180, Publication No. 20130164233 A1

99. Juliano, B.O. (1985). Rice: Chemistry and Technology, $2_{\text {nd }}$ ed. American Association of Cereal Chemists. St. Paul, MN, USA.

100. Hamada, J.S., A.M. Spanier, J.M. Bland and M. Diack (1998). Preparative separation of value-added peptides from rice bran proteins by high-performance liquid chromatography. J. Chromatogr. A., 827: 319-327.

101. Parrado, J., E. Miramontes, L. Terán and J. Bautista (2006). Preparation of a rice bran enzymatic extract with potential use functional food. Food Chem., 98,742-748.

102. Kahn, V. (1985). Effect of proteins, protein hydrolyzates, and amino acids on odihydroxyphenolase activity of polyphenol oxidase of mushroom, avocado, and banana. J. Food Sci., 50: 111-115.

103. Ali, H.M., A.M. El-Gizawy, R.E. El-Bassiouny and M.A. Saleh (2016). The role of various amino acids in enzymatic browning process in potato tubers, and identifying the browning products. Food Chem., 192, 879-885.

104. Supatcha, K. and T. Chockchai (2014). Effect of rice bran protein extract on enzymatic browning inhibition in vegetable and fruit puree. Kasetsart Journal - Natural Science, 48(2),205-213.

105. Teeraniti, L., K. Supatcha and Th. Chockchai (2020). Inhibitory effect of rice bran protein and its fractions on enzymatic browning in potato puree. Agr. Nat. Resour. 54(3), 301-308.

106. Grifths, G.; Trueman, L.; Crowther, T.; Thomas, B.; Smith, B. Onions-A global benefit to health. Phytother. Res. 2002, 16, 603-615.

107. Lee, B.; Seo, J.D.; Rhee, J.K.; Kim, C.Y. (2016) Heated apple juice supplemented with onion has greatly improved nutritional quality and browning index. Food Chem., 201, 315-319.

108. Kim, M.J. C.Y. Kim and I. Park (2005). Prevention of enzymatic browning of pear by onion extract. Food Chem., 89, 181-184.

109. Yapi JC., SN. Gnangui and S. Dabonne (2015). Inhibitory effect of onions and garlic extract on the enzymatic browning of an edible yam (Dioscorea cayenensisrotundata cv. Kponan) cultivated. Int. J. Curr Res. Acad. Rev., 3(1),219-231

110. Wong C. and A. Lee (2014). Inhibitory effect of onion extract on cassava leaf (Manihot esculenta Crantz) polyphenol oxidase. Int. Food Res. J., 21(2),755-758.

111. Akhtar, S. (2015). Advances in conventional breeding approaches for postharvest quality improvement in vegetables. In: Siddiqui MW (ed) Postharvest biology and technology of horticultural crops: principles and practices for quality maintenance. CRC Press, Boca Raton, pp 141-192.

112. Woo, K.S., I.G. Hwang and H. Jeong (2007). Changes in the antioxidant activity of onion (Allium cepa) extracts with heat treatment. Food Sci. Biotechnol., 16, 828-831.

113. Lee, M.K., Y.M Kim, N.Y. Kim, G.N. Kim, S.H. Kim, K.S. Bang and I. (2002). Prevention of browning in potato with a heat-treated onion extract. Biosci. Biotechnol. Biochem., $66,856-858$.

114. Honisch, C., A. Osto, M. A. Dupas, S. Vincenzi, and P. Ruzza (2020). Isolation of a tyrosinase inhibitor from unripe grapes juice: A spectrophotometric study. Food Chem., 305, 125506.

115. Lozano, P., D. Barrett, R. Wrolstad and R.(1993). Durst Enzymatic browning inhibited in fresh and dried apple rings by pineapple juice. J. Food Sci., 58, 399-404.

116. Brütsch, L., S. Rugiero, S. Serrano, et al., (2018). Targeted inhibition of enzymatic browning in wheat pastry dough. J. Agric. Food Chem., 66, 12353-12360.

117. Rakariyatham, K., Zhou, D., Rakariyatham, N., Shahidi, F. (2020). Sapindaceae (Dimocarpus longan and Nepheliumlappaceum) seed and peel by-products: 
Potential sources for phenolic compounds and use as functional ingredients in food and health applications. J. Funct. Foods, 67, 103846.

118. Prasad, K.N.; Yang, B.; Shi, J.; Yu, C.; Zhao, M.; Xue, S.; Jiang, Y. (2010). Enhanced antioxidant and antityrosinase activities of longan fruit pericarp by ultra-highpressure-assisted extraction. J. Pharm. Biomed. Anal., 51, 471-477.

119. Rangkadilok, N., S. Sitthimonchai, C. Mahidol, M. Ruchirawat, and J. Satayavivad (2007). Evaluation of free radical scavenging and antityrosinase activities of standardized longan fruit extract. Food Chem. Toxicol., 45, 328-336.

120. Martín, B., A. Torregrosa, and J. Garcia (2010). Post-bloom thinning of peaches for canning with hand-held mechanical devices. Sci. Hortic., 125, 658-665.

121. Redondo, D., R. Oria and E. Arias (2016), Inhibitory effect of microwaved thinned nectarine extracts on polyphenol oxidase activity. Food Chem., 197, 603-610.

122. Moco, S., E. Capanoglu, Y. Tikunov, R.J. Bino, D. Boyacioglu, R.D. Hall, and R.C. De Vos (2007). Tissue specialization at the metabolite level is perceived during the development of tomato fruit. J. Exp. Bot., 58, 4131-4146.

123. Martínez, G.B., N. Castillejo and F. Artés (2019). Effect of fresh-cut apples fortification with lycopene microspheres, revalorized from tomato by-products, during shelf life. Postharvest Biol. Technol., 156, 110925.

124. Lee, B., J.D. Seo, J.K. Rhee, C.Y. Kim (2016). Heated apple juice supplemented with onion has greatly improved nutritional quality and browning index. Food Chem., 201, 315-319.

125. Jun, L., W. Hui, L. Yang, M. Tang, X. Jiang, H.Sheng and L. Hui (2019). Inhibitory effect of Tartary buckwheat seedling extracts and associated flavonoid compounds on the polyphenol oxidase activity in potatoes (Solanum tuberosum L.). Journal of Integrative Agriculture, 18(9): 2173-2182.

126. Holzwarth, M., Wittig, J., Carle, R., \& Kammerer, D. R. (2012). Influence of putative polyphenol oxidase (PPO) inhibitors on strawberry (Fragaria x ananassa Duch.) PPO, anthocyanin, and color stability of stored purées. LWT-Food Science and Technology, 52(2), 1-12.

127. Ozoglu, H., \& Bayindirli, A. (2002). Inhibition of enzymic browning in cloudy apple juice with selected antibrowning agents. Food Control, 13(4), 213-221. 
|RAD|

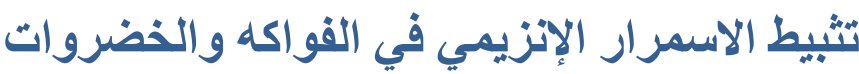

عمر يونس العباسي، وثبة ادريس علي، نشوان ابراهيم اللهيبي

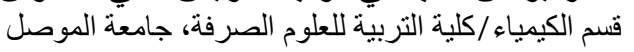

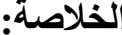

ان ثاني أكبر سبب لفقدان الجودة في الفواكه والخضروات هو الاسمرار الإنزيمي. ويساهم اللون البني الإنزيمي في جودة ألير ألوان منتجات الفاكهة

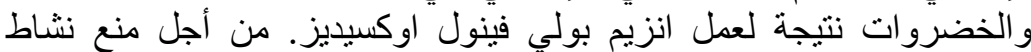

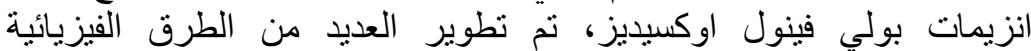

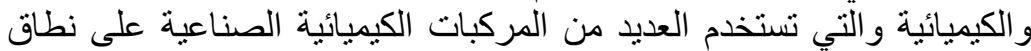

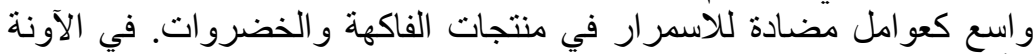
الأخيرة. يميل المستهلكون إلى تشجيع استخدام مثبطات انزيم بولي فئي فينول

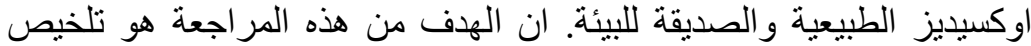

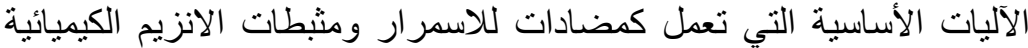

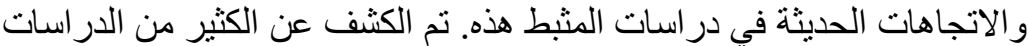
التي تم تطويرها على مدار العقد الماضي ومناقشتها، منل التقنيات الكيميائية

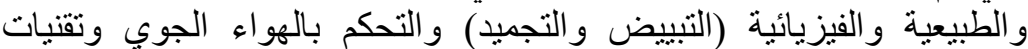
التغليف لمنع حدوث اللون البني الإنزيمي. ان الغرض من ولنه هذه المقالة هو جمع

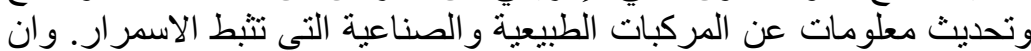

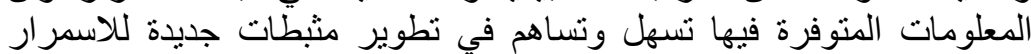

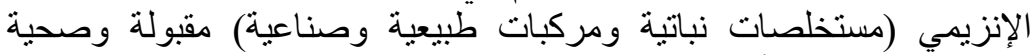
ومفيدة في صناعة الأغذية.
معلومات البحث:

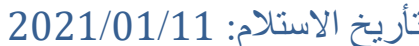
تأريخ القبـــــ 2021/02/25

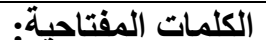

الاسمرار الإنزيهي، بولي فينول

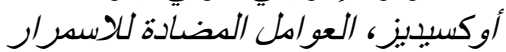

